\title{
Developing a competency-based medical education curriculum for the core basic medical sciences in an African Medical School
}

This article was published in the following Dove Press journal:

Advances in Medical Education and Practice

18 July 2016

Number of times this article has been viewed

Funmilayo Eniola Olopade'

Oluwatosin Adekunle

Adaramoye ${ }^{2}$

Yinusa Raji ${ }^{3}$

Abiodun Olubayo Fasola ${ }^{4}$

Emiola Oluwabunmi

Olapade-Olaopa ${ }^{5}$

'Department of Anatomy,

2Department of Biochemistry,

${ }^{3}$ Department of Physiology,

${ }^{4}$ Department of Oral Pathology,

${ }^{5}$ Department of Surgery, College

of Medicine, University of Ibadan,

lbadan, Nigeria
Correspondence: Emiola Oluwabunmi Olapade-Olaopa

Department of Surgery, College of Medicine, University of Ibadan, PO Box

7193 Secretariat, Ibadan, Nigeria

Tel +2348I 86774485

Email okeoffa@gmail.com
Abstract: The College of Medicine of the University of Ibadan recently revised its MBBS and BDS curricula to a competency-based medical education method of instruction. This paper reports the process of revising the methods of instruction and assessment in the core basic medical sciences directed at producing medical and dental graduates with a sound knowledge of the subjects sufficient for medical and dental practice and for future postgraduate efforts in the field or related disciplines. The health needs of the community and views of stakeholders in the Ibadan medical and dental schools were determined, and the "old" curriculum was reviewed. This process was directed at identifying the strengths and weaknesses of the old curricula and the newer competences required for modern-day medical/dental practice. The admission criteria and processes and the learning methods of the students were also studied. At the end of the review, an integrated, system-based, community-oriented, person-centered, and competency-driven curriculum was produced and approved for implementation. Four sets of students have been admitted into the curriculum. There have been challenges to the implementation process, but these have been overcome by continuous faculty development and reorientation programs for the nonteaching staff and students. Two sets of students have crossed over to the clinical school, and the consensus among the clinical teachers is that their knowledge and application of the basic medical sciences are satisfactory. The Ibadan medical and dental schools are implementing their competency-based medical education curricula successfully. The modifications to the teaching and assessment of the core basic medical science subjects have resulted in improved learning and performance at the final examinations.

Keywords: competency-based medical education, curriculum revision, basic medical science, integration

\section{Background}

The regular review of curricula is necessary to ensure that these instruments for student instruction reflect changes in the society and are thus contemporary. ${ }^{1}$ Major revision of medical/dental curricula is recommended every 5 years as half of all medical knowledge becomes outdated within this period. ${ }^{2}$

Most sub-Saharan medical/dental schools are still using the curricula adopted from their colonial masters at the time of inception of the schools several decades ago. ${ }^{3}$ This has meant that the schools are largely out of tune with the health needs of their societies and with contemporary medical education. ${ }^{4,5}$

The current health care challenges faced by sub-Saharan Africa (SSA) are particularly severe and demand that the continent's medical/dental schools produce graduates who are able to respond to the peculiar needs of their community. Competency-based 
medical education (CBME) is an outcome-based training model that concentrates on equipping the graduate with knowledge, skills, and attitudes that are relevant to the host community. ${ }^{6,7}$ This educational model is adjudged to be most suited for rapidly changing health needs of individual communities and is increasingly being adopted by medical schools worldwide including SSA in order to equip graduates with the skills required for contemporary medical and dental practice in the continent. ${ }^{7-10}$

The College of Medicine of the University of Ibadan (CMUI) recently completed a review of its MBBS and BDS (preclinical) curricula, which produced what we believe are the first entirely home-grown curricula in SSA. ${ }^{11}$ This paper reports on the revision process as it applies to the core basic medical sciences component of the curriculum, that is, anatomy, biochemistry, and physiology.

\section{Methods}

The curriculum revision was undertaken through a series of overlapping processes that took place from 2001 to 2012 , described briefly in another paper. ${ }^{10} \mathrm{~A}$ summary is presented in the subsections below.

\section{Capacity building}

Preparatory to the curricular reform, seven CMUI academic staff (four from the Faculty of Clinical Sciences and three from the Faculty of Basic Medical Sciences) undertook formal training in medical education both locally and internationally. ${ }^{12}$ These academic staff members formed the core of the teams charged with directing various aspects of the curriculum reform process.

\section{Needs assessment (200I-2006)}

During this period, the opinions of the various stakeholders in the CMUI MBBS and BDS curriculum (college executives, teaching and nonteaching staff, medical/dental students, employers of doctors, and members of the public) were sought on the kind of doctors and dentists needed, using questionnaires, interviews, and discourses. In the end, the consensus was that graduates of the medical and dental schools were not meeting the current and future health needs of the country. Therefore, a curriculum review was deemed necessary.

Later in 2004, the university received a capacity strengthening grant from the John $\mathrm{T}$ and Catherine D MacArthur foundation, and revision of the MBBS curriculum was selected as a pilot for a university-wide curricula revision. One of the authors (EOO) was appointed as the principal investigator.

\section{Reforming the curriculum (2005-20I0)}

The curriculum reform was done by a Curriculum Review Committee working in partnership with the College Curriculum Committee. The committee included college executives and representatives from all departments/disciplines contributing to the MBBS and BDS curricula and student representatives.

The Curriculum Review Committee critically evaluated the previous curriculum and consulted contemporary national and international medical curriculum guidelines. ${ }^{13-16}$ It also scrutinized the admission process, especially the entry criteria, and studied the learning processes of the students. ${ }^{17}$ This review process identified the strengths and weaknesses of the old MBBS and BDS curriculum (Table 1). Further deliberations of the committee considered different curricular philosophies and identified CBME curriculum as the most appropriate method of instruction to produce doctors who are "fit for-practice" in contemporary Nigeria.

Following the review, the curriculum was then wholly revised by restructuring the old teaching and assessment

Table I Strengths and weaknesses identified in the "old" traditional CMUI curriculum for MBBS/BDS

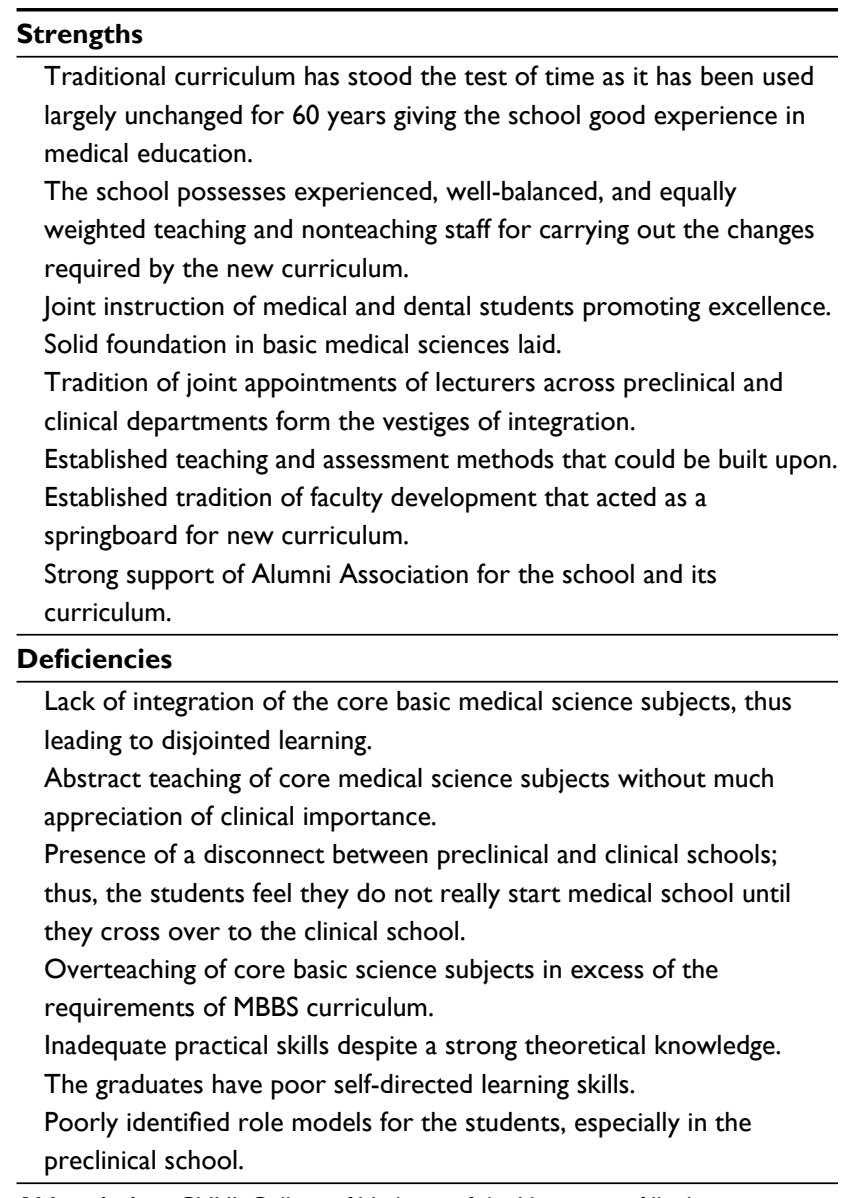

Abbreviation: CMUI, College of Medicine of the University of Ibadan. 
methods, repackaging the old courses, and adding new ones to ensure acquisition of the desired competences.

\section{Restructuring of the teaching schedule of the core basic medical sciences}

The 2010 curricula retained the general framework of the old MBBS and BDS curricula, that is, length of study (5 years) and the concept of preclinical and clinical schools with the first three semesters focusing on learning the core basic medical sciences. The MBBS and BDS part 1 final examinations were also retained in place and structure (Table 2). However, the internal arrangement of the curricula was modified in the revised version. With this rearrangement, the core basic medical sciences were to be taught in a horizontally integrated fashion in the first two semesters, while the third semester was dedicated to the vertical integration of the core basic medical sciences with laboratory medicine and clinical sciences. This restructuring focused on teaching of the basic science subjects on MBBS/BDS requirements. It also allowed new courses to be added to the teaching schedule (see "Introduction of new courses" and Figure 1).

\section{Introduction of new courses}

Courses relevant for future medical and dental practice were introduced at this level of instruction. These include the "medicine/dentistry as a profession" course to give the students an early orientation into the professional demands of medical and dental practice. Another is the "multidisciplinary healthcare delivery" course that comprises joint team-based learning sessions with students of other health professions (nursing, physiotherapy, human nutrition, and pharmacy) to give them an early orientation to team-based approach to health care, which is necessary for effective and efficient patient care. The "clinical application of basic medical sciences" course was also added in the third semester to ensure an early exposure of the students to clinical and laboratory medicine scenarios so they can have a better understanding of the relevance of the basic medical sciences to subsequent clinical science learning and medical/dental practice.

\section{Development of competency-based curricula \\ Determination of desired competencies learning objectives}

To ensure that the revised CMUI curriculum was competencybased, teachers from each of the core basic medical science departments identified the desired competences (learning objectives) for medical students in the basic medical sciences, drawing from the needs assessment done earlier. The core learning objectives of the basic medical sciences were:

1. To produce medical graduates who have sound knowledge and skills of basic medical sciences that are sufficient for medical education of global standards.

2. To introduce students to the clinical applications of basic medical sciences.

3. To produce medical graduates with a general knowledge of research in basic medical sciences.

Subsequent to this, "desired competencies" as "learning objectives" were identified for each course, and the methods of teaching and assessment that would guide learning in this direction were developed based on the needs assessments done earlier in the revision process (Table 2).

\section{Acquisition of prioritization of learning}

To further guide the students in prioritizing their learning, the curriculum content was classified into "must know/ must know to pass", "should know/should know to pass", and "may know/may know to pass", which were allotted $50 \%, 30 \%$, and $10 \%$, respectively, of the instruction time (Table 3). The "must-knows" are compulsory competencies that the student must possess in order to pass an examination in that area, while the "should-knows" are desirable but not compulsory and "may-knows" are nonessential competencies for the course.

\section{Modification of teaching methods}

In recognition of the fact that medicine and dentistry are primarily professions of skills, the new curriculum places a greater emphasis on the acquisition of these practical skills, with the ratio of percentage of time allotted to practical classes and didactic lectures being 60:40. Additionally, to encourage a deep approach to learning, small group tutorials were allotted $60 \%$ of the time for didactic lectures. These tutorial groups are to ensure that students are effectively mentored and their progress is closely monitored. Additionally, the tutorials are to use aspects of the problem-based learning model to encourage early acquisition of self-learning skills. To further engender the skills of self-directed learning and teamwork, individual and group term papers were also introduced, which would be assessed formatively and summatively.

\section{Modification to the assessment methods}

The assessment methods of the students were standardized and include formative (nonconsequential) and summative 
Table 2 Learning methods for anatomy, biochemistry, and physiology for MBBS and BDS

\begin{tabular}{|c|c|c|c|}
\hline Learning objective & Outcome measures/indices & Assessment methods & Teaching methods \\
\hline \multicolumn{4}{|l|}{ Anatomy } \\
\hline $\begin{array}{l}\text { Possess knowledge of anatomy } \\
\text { sufficient for medical education }\end{array}$ & $\begin{array}{l}\text { Demonstration of theoretical } \\
\text { and practical knowledge of } \\
\text { gross human anatomy }\end{array}$ & $\begin{array}{l}\text { MCQs, long and short essay } \\
\text { questions, practical examination } \\
\text { (steeplechase) and viva voce } \\
\text { (cards), picture test }\end{array}$ & $\begin{array}{l}\text { Didactic lectures (core basic } \\
\text { medical sciences), tutorial, practical } \\
\text { demonstrations, slide shows, } \\
\text { E-learning materials }\end{array}$ \\
\hline $\begin{array}{l}\text { To possess adequate } \\
\text { orientation toward application } \\
\text { of basic medical sciences in } \\
\text { clinical practice }\end{array}$ & $\begin{array}{l}\text { Demonstration of theoretical } \\
\text { and practical knowledge of } \\
\text { microscopic structures of } \\
\text { human tissues and organs using } \\
\text { clinical correlates }\end{array}$ & $\begin{array}{l}\text { MCQs, long and short essay } \\
\text { questions, practical examination } \\
\text { (steeplechase), and viva voce } \\
\text { (cards), picture test }\end{array}$ & $\begin{array}{l}\text { Didactic lectures (applied basic medical } \\
\text { sciences), tutorial, gross dissections, } \\
\text { dlide shows and histological practical } \\
\text { sessions, E-learning materials, } \\
\text { case-based learning }\end{array}$ \\
\hline $\begin{array}{l}\text { Competence in basic research } \\
\text { methodology }\end{array}$ & $\begin{array}{l}\text { Demonstration of basic } \\
\text { research methods }\end{array}$ & $\begin{array}{l}\text { MCQs, long and short essay } \\
\text { questions, practical examination }\end{array}$ & $\begin{array}{l}\text { Didactic lectures, tutorial, take-home } \\
\text { research assignments }\end{array}$ \\
\hline
\end{tabular}
methodology research methods questions, practical examination (steeplechase) and viva voce (cards), picture test

To possess sound knowledge of basic medical sciences of international standards
Demonstration of sound understanding of human developmental process (embryology), gross anatomy, histology and neuroanatomy, and basic concept of molecular biology
MCQs, long and short essay questions, practical examination (steeplechase) and viva voce (cards), picture test research assignments

Didactic lectures, tutorial, take-home research, assignments, gross dissections, slide shows and histological practical sessions, E-learning materials

\section{Biochemistry}

To acquire adequate knowledge of biochemistry and molecular biology for medical education

Competence in clinical applications of basic biochemistry

To possess sound knowledge of basic research methodologies in biochemistry and molecular biology

To produce medical graduates whose knowledge of biochemistry is of international standard

\section{Physiology}

To produce medical graduates who have sufficient knowledge of basic physiology

To produce medical graduates who have adequate orientation toward application of basic physiology in clinical practice

To produce medical graduates with knowledge of basic research methodology

To produce medical graduates who have sound knowledge of basic physiology of international standards
Practical and theoretical knowledge of the biochemical basis of human diseases

Sound application of biochemistry in the clinics

Ability to interpret correctly the results of different diagnostic tests (for example, creatinine, urea, PSA, Western blot, PCR) in human diseases

Up to date knowledge of biochemistry (the use of gene therapy, AuroLase therapy, etc, to treat cancer)
Didactic lectures, practical sessions, tutorials, E-learning materials

short answer questions, practical and oral examinations

Essay questions (long and short), practical and oral examinations, picture test

Essay questions (long and short), term papers and practical examinations

Didactic lectures, tutorial, take-home assignments

Didactic lectures, practical sessions, E-learning methods

Essay questions (long and short), practical and oral examinations
Didactic lectures, practical sessions

\section{Demonstration of adequate MCQs, long and short essay theoretical knowledge of basic questions, practical examinations physiologic functions and mechanism (steeplechase), orals, SAQs in various systems in humans \\ Demonstration of basic practical knowledge of systems and organs in humans \\ MCQs, long and short essay questions practical examination (steeplechase), orals \\ Didactic lectures (core basic medical sciences), tutorials, mini-projects, practical demonstrations, E-learning materials \\ Didactic lectures, tutorials, mini-projects, practical demonstrations, case-based learning}

Ability to apply basic physiology in clinical sciences, demonstration of basic research methodology Demonstration of sound understanding of human, developmental process (embryology), gross anatomy, histology and neuroanatomy, and basic concept of molecular biology
MCQs, long and short essay questions, practical examination (steeplechase), orals

MCQs, long and short essay questions, practical examination (steeplechase), orals
Didactic lectures, tutorials, mini-projects, practical demonstrations

Didactic lectures, tutorials, mini-projects, practical demonstrations

Abbreviations: PCR, polymerase chain reaction; PSA, prostate-specific antigen; MCQs, multiple choice questions; SAQs, short answer questions. 


\section{GRAPHIC REPRESENTATION OF 2010 CMUI INTEGRATED CURRICULUM}

\begin{tabular}{|c|c|c|c|c|c|c|c|c|c|c|c|c|c|c|c|c|c|c|c|c|c|c|c|c|}
\hline \multirow{2}{*}{$\begin{array}{c}\text { Beginning } \\
\text { of } \\
\text { sessions }\end{array}$} & \multicolumn{24}{|c|}{ Weeks } \\
\hline & 2 & 4 & 6 & 8 & 10 & 12 & 14 & 16 & 18 & 22 & 24 & 26 & 28 & 30 & 32 & 34 & 36 & 40 & 42 & 44 & 46 & 48 & 50 & 52 \\
\hline $200 \mathrm{~L}$ & GIP & \multicolumn{4}{|c|}{$\begin{array}{c}\text { Integrated core } \\
\text { basic science } \\
\text { । }\end{array}$} & 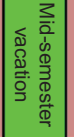 & \multicolumn{3}{|c|}{$\begin{array}{c}\text { Integrated core } \\
\text { basic science } \\
\text { I }\end{array}$} & \multicolumn{2}{|c|}{$\begin{array}{l}\text { Medicine } \\
\quad \text { as a } \\
\text { profession }\end{array}$} & 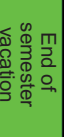 & \multicolumn{4}{|c|}{$\begin{array}{l}\text { Integrated core } \\
\text { basic science } \\
\text { II }\end{array}$} & 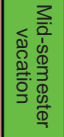 & \multicolumn{3}{|c|}{$\begin{array}{c}\text { Integrated core } \\
\text { basic science } \\
\text { II } \\
\text { and PHS (PSM I) }\end{array}$} & $\begin{array}{r}\text { ML } \\
\text { discip } \\
\text { health } \\
\text { deli }\end{array}$ & $\begin{array}{l}\text { Iti- } \\
\text { inary } \\
\text { care } \\
\text { sery }\end{array}$ & \multicolumn{2}{|c|}{$\begin{array}{l}\text { End of } \\
\text { session } \\
\text { vacation }\end{array}$} \\
\hline \multirow[b]{2}{*}{$300 \mathrm{~L}$} & \multirow{2}{*}{\multicolumn{2}{|c|}{$\begin{array}{c}\text { Integrated } \\
\text { block posting } \\
\text { I }\end{array}$}} & \multicolumn{6}{|c|}{ Integrated system-based lectures } & \multirow{2}{*}{$\begin{array}{l}\text { Revision } \\
\text { of core } \\
\text { basic } \\
\text { sciences }\end{array}$} & \multirow{2}{*}{ 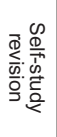 } & \multirow{2}{*}{$\begin{array}{l}\text { MBBS } \\
\text { Part I } \\
\text { exam }\end{array}$} & \multirow{2}{*}{ 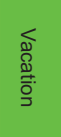 } & \multirow{2}{*}{\multicolumn{2}{|c|}{$\begin{array}{c}\text { Clinical } \\
\text { introductory } \\
\text { posting }\end{array}$}} & \multicolumn{5}{|c|}{ Integrated lectures } & \multirow{2}{*}{\multicolumn{4}{|c|}{$\begin{array}{l}\text { Integrated block } \\
\text { posting } \\
\text { II }\end{array}$}} & \multirow{2}{*}{ 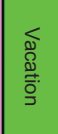 } \\
\hline & & & \multicolumn{6}{|c|}{$\begin{array}{l}\text { Integrated clinical } \\
\text { application of basic } \\
\text { sciences }\end{array}$} & & & & & & & \multicolumn{5}{|c|}{$\begin{array}{l}\text { Integrated introductory } \\
\text { medicine I and surgery I }\end{array}$} & & & & & \\
\hline \multirow[b]{2}{*}{$400 \mathrm{~L}$} & Break & \multicolumn{6}{|c|}{ Integrated system-based lectures } & Break & \multicolumn{6}{|c|}{ Integrated system-based lectures } & & eak & \multicolumn{6}{|c|}{ Integrated system-based lectures } & \multicolumn{2}{|c|}{ Break } \\
\hline & \multicolumn{2}{|c|}{ Radiology I } & \multicolumn{4}{|c|}{ Junior pediatrics } & \multicolumn{3}{|c|}{ Medicine II } & \multicolumn{4}{|c|}{ Surgery II } & \multicolumn{4}{|c|}{ Junior OBGYN } & \multicolumn{3}{|c|}{ Special posting I } & $\begin{array}{l}\text { Infect } \\
\text { disea } \\
\text { post }\end{array}$ & $\begin{array}{l}\text { lous } \\
\text { ses } \\
\text { ing }\end{array}$ & $\begin{array}{l}\text { (PSI } \\
\text { comm } \\
\text { medic }\end{array}$ & $\begin{array}{l}\text { M II) } \\
\text { nunity } \\
\text { cine I }\end{array}$ \\
\hline $500 \mathrm{~L}$ & 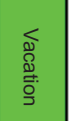 & Psych & iatry I & $\begin{aligned} \mathrm{Fa} \\
\mathrm{mec}\end{aligned}$ & $\begin{array}{l}\text { mily } \\
\text { cine I }\end{array}$ & $\begin{array}{l}\text { Bloc } \\
\text { postir } \\
\text { revisi }\end{array}$ & & $\begin{array}{l}\text { MBBS } \\
\text { Part II } \\
\text { exam }\end{array}$ & Senior $\mathrm{f}$ & ediatric & & & enior $\mathrm{OB}$ & BGYN & & & $\begin{array}{l}\text { (PSN } \\
\text { no-Ora } \\
\text { nmunity }\end{array}$ & $\begin{array}{l}\text { posting } \\
\text { medicine }\end{array}$ & & $\begin{array}{r}\text { Rev } \\
\text { OBGY } \\
\text { pedi }\end{array}$ & $\begin{array}{l}\text { ision } \\
\mathrm{N} \text { and } \\
\text { atrics }\end{array}$ & & 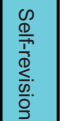 & $\begin{array}{l}\text { MBBS } \\
\text { Part III } \\
\text { exam }\end{array}$ \\
\hline $600 \mathrm{~L}$ & 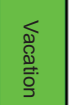 & Psychi & atry II & & & $\begin{array}{r}\text { Fami } \\
\text { medicir }\end{array}$ & ily & & ecial posting & & Radiol & gy II & 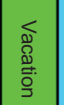 & Comn & $\begin{array}{r}\text { (PSN } \\
\text { amunit) } \\
\text { II }\end{array}$ & $\begin{array}{l}\text { U IV) } \\
\text { y med } \\
\text { II }\end{array}$ & cine & Medici & e III & and sur & gery II & & \begin{tabular}{l|}
$\frac{\infty}{\infty}$ \\
$\frac{\infty}{\frac{1}{D}}$ \\
$\frac{1}{\infty}$ \\
$\frac{\infty}{0}$ \\
$\frac{0}{0}$
\end{tabular} & $\begin{array}{l}\text { MBBS } \\
\text { Part IV } \\
\text { exam }\end{array}$ \\
\hline
\end{tabular}

Figure I Graphic representation of $2010 \mathrm{CMUI}$ integrated curriculum.

Abbreviations: CMUI, College of Medicine of the University of Ibadan; GIP, general introductory; OBGYN, obstetrics and gynecology; Exam, examination; PSM, preventive and social medicine; PHS, public health science.

Table 3 Desired competences for anatomy, biochemistry, and physiology for MBBS

\begin{tabular}{|c|c|c|c|c|}
\hline Learning objective & Outcome indices & $\begin{array}{l}\text { Must know/must know } \\
\text { to pass, } \mathbf{5 0} \% \text { contact } \\
\text { teaching time }\end{array}$ & $\begin{array}{l}\text { Should know/should } \\
\text { know to pass, } 30 \% \\
\text { contact teaching time }\end{array}$ & $\begin{array}{l}\text { May know/may know } \\
\text { to pass, } 10 \% \text { contact } \\
\text { teaching time }\end{array}$ \\
\hline \multicolumn{5}{|l|}{ Anatomy } \\
\hline $\begin{array}{l}\text { Possess knowledge of } \\
\text { anatomy sufficient for } \\
\text { medical education }\end{array}$ & $\begin{array}{l}\text { Demonstration of } \\
\text { theoretical and practical } \\
\text { knowledge of gross and } \\
\text { microscopic structures in } \\
\text { human anatomy }\end{array}$ & $\begin{array}{l}\text { Normal structure (gross } \\
\text { and microscopic) of the } \\
\text { human body, understanding } \\
\text { of the developmental } \\
\text { process, surface anatomy of } \\
\text { various regions of the body }\end{array}$ & $\begin{array}{l}\text { Sexual differences in } \\
\text { anatomical structures, } \\
\text { anatomical positions of } \\
\text { structures in the body }\end{array}$ & $\begin{array}{l}\text { Anatomical variants that } \\
\text { occur (both normal and } \\
\text { abnormal) }\end{array}$ \\
\hline $\begin{array}{l}\text { To introduce students to } \\
\text { simple clinical applications } \\
\text { of basic anatomy }\end{array}$ & $\begin{array}{l}\text { Demonstration of } \\
\text { theoretical and practical } \\
\text { knowledge of microscopic } \\
\text { structures of human tissues } \\
\text { and organs using clinical } \\
\text { correlates. Ability to apply } \\
\text { the knowledge of anatomy } \\
\text { in clinical setting }\end{array}$ & $\begin{array}{l}\text { Understanding of the } \\
\text { anatomical basis of various } \\
\text { clinical conditions }\end{array}$ & $\begin{array}{l}\text { Clinical outcome expected } \\
\text { from specific aberrations of } \\
\text { human anatomic structures }\end{array}$ & $\begin{array}{l}\text { Various clinical } \\
\text { syndromes produced } \\
\text { by disturbances in the } \\
\text { developmental process }\end{array}$ \\
\hline $\begin{array}{l}\text { Various clinical syndromes } \\
\text { produced by disturbances } \\
\text { in the developmental } \\
\text { process }\end{array}$ & $\begin{array}{l}\text { Demonstration of basic } \\
\text { research methods }\end{array}$ & & $\begin{array}{l}\text { How to carry out simple } \\
\text { research in anatomy }\end{array}$ & \\
\hline
\end{tabular}


Table 3 (Continued)

\begin{tabular}{|c|c|c|c|c|}
\hline $\begin{array}{l}\text { To possess sound } \\
\text { knowledge of anatomy of } \\
\text { international standards }\end{array}$ & $\begin{array}{l}\text { Demonstration of sound } \\
\text { understanding of human } \\
\text { developmental process } \\
\text { (embryology), gross } \\
\text { anatomy, histology and } \\
\text { neuroanatomy and, basic } \\
\text { concept of molecular } \\
\text { biology }\end{array}$ & $\begin{array}{l}\text { Up-to-date anatomical } \\
\text { nomenclature, basic } \\
\text { computer skills in getting } \\
\text { knowledge online }\end{array}$ & & \\
\hline \multicolumn{5}{|l|}{ Biochemistry } \\
\hline $\begin{array}{l}\text { To acquire adequate } \\
\text { knowledge of biochemistry } \\
\text { and molecular biology for } \\
\text { medical education }\end{array}$ & $\begin{array}{l}\text { Practical and theoretical } \\
\text { knowledge of the } \\
\text { biochemical basis of human } \\
\text { diseases }\end{array}$ & $\begin{array}{l}\text { The structure, chemistry, } \\
\text { and function of normal } \\
\text { living cell; metabolism of } \\
\text { proteins, carbohydrates, } \\
\text { nucleic acids, and lipids; } \\
\text { Basic biochemical functions } \\
\text { of kidney and liver }\end{array}$ & $\begin{array}{l}\text { The role of electron } \\
\text { transport chain and } \\
\text { oxidative phosphorylation } \\
\text { in the generation of ATP. } \\
\text { Genetic regulation of } \\
\text { cellular metabolism }\end{array}$ & $\begin{array}{l}\text { Translocation and gene } \\
\text { rearrangement in disease } \\
\text { state }\end{array}$ \\
\hline $\begin{array}{l}\text { Competence in clinical } \\
\text { applications of basic } \\
\text { biochemistry }\end{array}$ & $\begin{array}{l}\text { Sound application of } \\
\text { biochemistry in the clinics }\end{array}$ & $\begin{array}{l}\text { Understanding the } \\
\text { nature, properties, and } \\
\text { clinical importance of } \\
\text { enzymes. Porphyrins, } \\
\text { hemoglobinopathies, } \\
\text { hybridoma technology in } \\
\text { medicine }\end{array}$ & $\begin{array}{l}\text { The biochemical functions } \\
\text { of biological membranes, } \\
\text { vitamins, hormones, } \\
\text { and clinical features of } \\
\text { abnormalities. Human } \\
\text { nutrition, plants-derived } \\
\text { diets, and malnutrition }\end{array}$ & $\begin{array}{l}\text { Biochemistry of aging, } \\
\text { nervous, and muscle } \\
\text { actions }\end{array}$ \\
\hline $\begin{array}{l}\text { To possess sound } \\
\text { knowledge of basic } \\
\text { research methodologies in } \\
\text { biochemistry and molecular } \\
\text { biology }\end{array}$ & $\begin{array}{l}\text { Ability to interpret } \\
\text { correctly the results of } \\
\text { different diagnostic tests } \\
\text { (eg, creatinine, urea, PSA, } \\
\text { Western blot, PCR) in } \\
\text { human diseases }\end{array}$ & $\begin{array}{l}\text { Detection of human } \\
\text { diseases with ELISA, PCR, } \\
\text { Western blot, and RIA } \\
\text { methods }\end{array}$ & $\begin{array}{l}\text { Retroviruses: involvement } \\
\text { in cancer, AIDS, and other } \\
\text { diseases }\end{array}$ & $\begin{array}{l}\text { Applications of } \\
\text { immunotherapy, assay of } \\
\text { hormones }\end{array}$ \\
\hline
\end{tabular}

\section{Physiology}

To produce medical graduates who have sufficient knowledge of basic physiology

To produce medical graduates who have adequate orientation toward application of basic physiology in clinical practice

To produce medical graduates with knowledge of basic research methodology

To produce medical graduates who have sound knowledge of basic physiology of international standards
Demonstration of adequate theoretical knowledge of basic physiologic functions and mechanism in various systems in humans

Demonstration of basic practical knowledge of systems and organs in humans
Ability to apply basic physiology in clinical sciences, demonstration of basic research methodology
Demonstration of sound theoretical and practical knowledge of basic functions and mechanism of human body in various systems and organs

$\begin{array}{lll}\begin{array}{l}\text { General principles of } \\ \text { physiology, cell physiology, }\end{array} & \begin{array}{l}\text { Basic structure of typical } \\ \text { cells, functional anatomy } \\ \text { membrane transport, }\end{array} & \begin{array}{l}\text { Basic biochemistry of } \\ \text { cell membrane, clinical }\end{array} \\ \text { homeostasis, blood, CVS, } & \begin{array}{l}\text { endocrine disorders } \\ \text { correlates in each system }\end{array} & \end{array}$
respiration, etc Introduction to physiology experiments, practical physiology on each body system and organ

Introduction to research methodology, proposal writing literature search

Mechanism of action of various physiological processes such as hormone and muscular contraction
Basic data analysis methods Interpretation of results

Relate clinical correlates

to basic physiological

processes

Abbreviations: ATP, adenosine triphosphate; ELISA, enzyme-linked immunosorbent assay; CVS, cardiovascular system; PCR, polymerase chain reaction; PSA, prostatespecific antigen; RIA, radioimmunoassay. 
(consequential) examinations. These reflect the prioritized teaching with courses described earlier, that is, $50 \%, 30 \%$, and $10 \%$ being allocated to the "must know to pass", "should know to pass", and "may know to pass", respectively (Table 3). The Part I MBBS and BDS final examination were retained at the end of the third semester but were modified to have an integrated component. Furthermore, the student must obtain $37.5 \%$ of the $50 \%$ total marks from the "must know" section and must pass all three basic science subjects with $\geq 50 \%$ of marks available.

\section{Horizontal integration}

The revision led to the development of a novel harmonized course schedule in which the students would receive lectures on the anatomy, biochemistry, and physiology of the same region or systems of the body in a concurrent fashion. Thus, the students would receive instructions on, for example, the anatomy of the digestive system, biochemical functions of gastrointestinal hormones, and physiology of gastrointestinal movements, digestion, and absorption of nutrients concurrently. To facilitate this harmonization, a "basic medical sciences for MBBS/BDS time table" was drawn up jointly by the three departments. The next step was the harmonization of the course contents of the basic medical science lectures. The lecture topics being taught were harmonized and synchronized to reduce repetition of teaching by the departments.

\section{Vertical integration}

The third semester of preclinical school was dedicated to vertical integration of basic medical sciences with laboratory medicine and clinical science disciplines (the clinical application of basic sciences). This course is to be taught by clinicians and laboratory medicine specialists alongside their basic science counterparts. A revision posting of the core basic medical sciences would be done before the Part I final examination, which would hold at the end of the third semester.

\section{Changes peculiar to each of the core basic medical science subjects Physiology}

Instructions in physiology had always been system based. This meant its schedule could be used as the template for horizontal integration with anatomy and biochemistry. The established order of giving these lectures was based on the proximity of functions and the complexity of the topic. For example, the respiratory system was taught just before the cardiovascular system and the gastrointestinal system just before the urinary system. However, the harmonization of topics with anatomy and biochemistry meant that this order was lost and the teachers were initially concerned about the change. In the end, the advantages of the harmonization of topics were considered to outweigh this perceived loss of order once the modification was accepted.

Given the objective of the revised curriculum that emphasized acquisition of practical skills, the practical sessions were expanded. A number of new sessions were developed in order to increase the breadth and the depth of the students' exposure and instruction in physiology. A definite effort was also made to ensure that the practical sessions followed the lecture sessions so as to consolidate learning as early as possible.

\section{Anatomy}

The main change peculiar to gross anatomy was the shift of paradigm from region-based to system-based teaching; this was a major thrust of the curriculum review. This was achieved by consensus or concurrent teaching where possible. A compromise schedule was designed in which the teaching of gross anatomy was done by regions, but once in a region, the systems in the region would be taught concurrently with other aspects of anatomy as well as physiology and biochemistry. The teaching session of the three modules of anatomy (gross anatomy, embryology, and histology) of the various systems was then horizontally integrated with the other basic medical science courses during instruction of the students.

\section{Biochemistry}

In the old curriculum, the established order for giving biochemistry lectures was to teach from simpler to more complex topics; however, the harmonization of topics with anatomy and physiology meant that this model had to be given up and topics taught in consonance. Also, adjustments were made to the schedule, and the fundamentals of biochemistry would still be taught first to ensure the students have a good foundation in the subject.

To achieve the objectives of the new curriculum, a number of topics in biochemistry that were considered as being in excess of the MBBS requirement were removed, thus allowing the students to concentrate on the more relevant topics. The practical schedule was also revamped, and modern topics in practical biochemistry relevant to medical training were retained.

\section{Institutional approval}

In line with the University of Ibadan 1986 Act, ${ }^{18}$ the revised MBBS curriculum was approved by the Academic Board of the 
College on April 2010 and was ratified by the university senate on August 30, 2010. Its operation commenced in the 2011/2012 academic year, and the fourth set of students has been admitted.

\section{Implementation}

The newly implemented curriculum has presented ample challenges to the institution, staff, and its students. Perhaps, the most striking challenge is the sense of uncertainty being felt by the students admitted under the revised curricula. This is because students usually look up to their seniors for guidance through the years of instruction. However, the senior students are unable to provide this guidance to their juniors as they are being trained under a different system (the old curriculum). This scenario has left the pioneer students under the revised curriculum feeling that they are the "guinea pig" set. On the other hand, the senior students are complaining of feeling abandoned as all attention is focused on implementing the revised curriculum. The senior students also have a sense of despair as they are concerned that their degrees may be considered inferior to those who graduate from the revised curricula. However, all these concerns have been ameliorated gradually as succeeding sets of students are admitted, and with increasing familiarly with the revised curriculum, by the teachers and students alike.

Implementing a revised curriculum is always expensive, especially as the teaching and nonteaching staff have to be trained and new facilities must be provided and teaching aids acquired. Fortunately, the University/College was awarded a 5-year grant from the Medical Education Partnership Initiative of the United States Government from which it has been able to provide part of the much-needed funds and international collaborations. ${ }^{19,20}$

The prioritization of knowledge to be learned by students is yet to be universally accepted as some teachers still expect the students to be conversant with all aspects of what they are taught regardless of emphasis. This has caused some degree of confusion and frustration on the part of the students, but the issue is being gradually resolved by retraining the teachers. In addition, the benefits of the introduction of "clinical applications of basic sciences" are yet to be fully realized. This is because although the students appreciate the clinical relevance of the basic medical sciences, they are still distracted from full participation in the lecture series since they are yet to take their Part I final examination, which involves mainly the core basic medical science subjects but includes tests on their clinical application. A reorientation for the teachers and students is ongoing in order for them to take full advantage of these innovations.

\section{Discussion}

Curricula are the guidelines for student instruction and must be reviewed regularly to keep them relevant to the changing needs of the society the institution serves. ${ }^{8}$ Thus, the revised CMUI MBBS and BDS curricula were directed at producing doctors who are best suited for 21 st-century Nigeria and possess competences that are of an international standard. They must also be socially responsive and accountable to the community, thus increasing in country retention. ${ }^{21}$ Importantly, these documents have been well received by the medical education fraternity and were the template for the first national template for MBBS and BDS curricula in Nigeria. ${ }^{22}$

Competency-based medical/dental education curricula are being adopted as the preferred instruments of medical instruction worldwide as they are adjudged to be better at producing fit-for-practice graduates for all communities. ${ }^{7,23}$ This is because the determining of the competencies desired to be acquired (which are derived from the host community's health needs) as a first step in the development of the curriculum (rather than the content) is a recent process that ensures that each instrument of instruction is unique to its institution/ locality and its vision and mission. This curricular philosophy also prescribes a convergence of teaching and assessment methods by all the subspecialties/disciplines contributing to the courses, as these are of necessity directed at achieving a common goal of producing a competent "generalist" doctor instead of attaining expertise in each subspecialty/discipline.

Revision of the CMUI MBBS and BDS basic medical science curricula was facilitated by the fact that at the level of basic medical science, the components of these two programs were similar in content and the students are majorly taught together. The new curriculum not only preserved this similarity but also enabled emphasis of the competencies peculiar to each program, especially in the clinical school. While these outcomes have led to a closer relationship between these programs, the latter advantage has contributed to the demand by the other health professional courses for competency-based curricula as it would emphasize their identities as distinct disciplines.

In keeping with modern principles of medical education, ${ }^{24,25}$ the methods of instruction and assessment in this revised curriculum have been chosen to suit our students and learning environment. ${ }^{10}$ In this manner, we took the fact that our students are admitted from secondary (high) school into consideration and adopted a hybrid curriculum that is a mixture of traditional didactic teaching and small group teaching (tutorials). The change in the methods of teaching and assessment of the basic medical sciences in the 
CMUI has been effective as the students now have a deeper understanding of the basic medical science concepts of both professions and are better mentored and prepared for clinical instruction. This improvement was achieved by the integration and prioritization of instruction, the increased small group teaching and practical sessions, and the emphasis on self-directed learning. Assessments have also been modified to compliment the revised teaching methods and to drive the required learning. To this end, the assessments test mainly the acquisition of basic science competencies required for medicine/medical practice with a proportion of the questions being integrated with either laboratory medicine or clinical science. Importantly, to obtain an overall pass in the final basic science examination for medicine and dentistry, our students are required to pass each basic science subject and to obtain a minimum mark in the "must know" section.

Expectedly, the effects of implementing the revised MBBS and BDS curricula on the college, its staff, and students have been significant. This is because CBME curricula require a change in the philosophy of achieving student learning, ${ }^{26}$ namely, changes to processes of faculty development, student instruction and assessment, strategies of institutional operation, monitoring and evaluation, and shared vision with regulatory bodies/government. ${ }^{27}$ Importantly, the institution is adjusting to the new philosophy of instruction by putting the necessary mechanisms in place to ensure as smooth a transition as is possible. We are presently on the temporal coordination level of integration on the "integration ladder" described by Harden ${ }^{28}$ and are working toward greater levels of integration in future. When combined with the decreased time allotted for teaching of the core basic medical sciences, this modification has been quite tasking for both students and teachers alike. However, seminars on pedagogy given to the teachers have better equipped them for teaching and to use the small group tutorials to fill in the gaps.

Four sets of students have been admitted since the approval of the curriculum in 2010. The first two of these sets have sat for the final basic medical science examinations and proceeded on to the applied basic and clinical sciences. Their knowledge of basic medical sciences and ability to apply the same to the clinical sciences, as adjudged by their clinical assessors, are at least comparable with, if not better than, that of the students in the previous curriculum. This has proved to be the litmus test for the revised curricula as they validate the CBME as a good model of instructing medical and dental students and certify the 2010 MBBS/BDS curricular reforms a success. These observations are particularly encouraging as the majority of studies on recent curricula revisions found that the learning of the basic sciences may be insufficient for clinical instruction. ${ }^{29-31}$ However, careful evaluation of the reports revealed that the curricula were mostly wholly problem-based learning based, and the students were required to achieve an overall pass in the final basic science examination with no sanction for any student who failed individual basic science components. We believe we have avoided this pitfall in our curriculum and indeed improved basic science learning by our students due to the adoption of a hybrid teaching model and a noncompensatory final assessment method that requires a pass in each basic science subject and a minimum mark in the "must know" section in order to obtain an overall pass.

Understandably, the successful revision of the MBBS and BDS curricula and their implementation has had a significant impact on the university and has led to agitation for similar revisions by other disciplines. Other health professional courses are particularly keen to revise their curricula into competency-based instruments having recognized the advantages on student learning.

\section{Conclusion}

The CMUI has recently revised its MBBS and BDS curriculum into a CBME curriculum that aims to produce doctors who are fit-for-practice in Nigeria now and in the future. This review included modification of the teaching and assessment of the core basic medical science subjects. Despite understandable (and expected) challenges of its implementation process, the project has been rewarding as it has resulted in improved learning and performance at the final examinations. A formal evaluation of the outcomes of this curriculum is being planned.

\section{Disclosure}

The authors report no conflicts of interest in this work.

\section{References}

1. Tyler RW. Basic Principles of Curriculum and Instruction. 2013 ed. Chicago, IL: The University of Chicago Press; 2013.

2. Baxter S [webpage on the Internet]. Pre-Med and Medical School Curriculum Reform. The CSUPERG Blog; 2011. Available from: http:// www.csuperb.org/blog/author/smbaxter/page/12/. Accessed July 3, 2014.

3. Gukas ID. Global paradigm shift in medical education: issues of concern for Africa. Med Teach. 2007;29(9):887-892.

4. Mullan F, Frehywot S, Omaswa F, et al. Medical schools in sub-Saharan Africa. Lancet. 2011;377(9771):1113-1121.

5. Greysen SR, Dovlo D, Olapade-Olaopa EO, Jacobs M, Sewankambo N, Mullan F. Medical education in sub-Saharan Africa: a literature review. Med Educ. 2011;45(10):973-986.

6. Frank JR, Danoff E. The CanMEDS initiative: implementing an outcomes-based framework of physician competencies. Med Teach. 2007;29(7):642-647.

7. Frank JR, Snell LS, Cate OT, et al. Competency-based medical education: theory to practice. Med Teach . 2010;32(8):638-645. 
8. Boelen C. Adapting health care institutions and medical schools to societies' needs. Acad Med. 1999;74(8 suppl):S11-S20.

9. Iputo JE, Nganwa-Bagumah AB. The innovative medical curriculum of the University of Transkei Medical School. Part II. Community-based learning. S Afr Med J. 1996;86(6):651-652.

10. Kiguli-Malwadde E, Olapade-Olaopa EO, Kiguli S, et al. Competencybased medical education in two Sub-Saharan Africa medical schools. Adv Med Educ Pract. 2014;5:1-7.

11. Olapade-Olaopa EO, editor. The 2010 MBBS Curriculum of the College of Medicine, University of Ibadan. Ibadan, Nigeria: Office of the Provost, College of Medicine, University of Ibadan; 2010:226.

12. Afolabi B, Olapade-Olaopa EO. International training in medical education - the FAIMER institute 2002 fellowship experience. Afr J Med Med Sci. 2006;35(1):59-67.

13. National Universities Commission. Benchmark Minimum Academic Standards for Undergraduate Programmes in Nigerian Universities. Abuja, Nigeria: NUC; 2007.

14. Medical and Dental Council of Nigeria. Medical and Dental Council of Nigeria Guideline on Minimum Standards of Medical and Dental Education in Nigeria. Nigeria: MDCN; 2006.

15. General Medical Council. Tomorrow's Doctors - Outcomes and Standards for Undergraduate Medical Education. London: GMC; 2009.

16. World Federation for Medical Education [homepage on the Internet]. Basic Medical Education; WFME Global Standards for Quality Improvement: The 2012 Revision. Copenhagen: WFME; 2012. Available from: http://www.wfme.org. Accessed March 12, 2015.

17. Olapade-Olaopa EO, Dania S, Soyannwo OA, Adeniyi FAA. Study processes of first year clinical students of the College of Medicine, University of Ibadan, Ibadan Nigeria. Afr J Med Med Sci. 2004;35(4):431-435.

18. College of Medicine of the University of Ibadan Statute (Statute No.2) [S.I. 30 of 1984]. Laws of Nigeria: University of Ibadan Act (1962 No.37); 1963.

19. Mullan F, Frehywot S, Omaswa F, et al. The medical education partnership initiative: PEPFAR's effort to boost health worker education to strengthen health systems. Health Aff (Millwood). 2012;331(7): $1561-1572$.
20. Olapade-Olaopa EO, Baird S, Kiguli-Malwadde E, Kolars JC. Growing partnerships: leveraging the power of collaboration through the medical education partnership initiative. Acad Med. 2014;89(8 suppl): S19-S23.

21. Olapade-Olaopa EO. Curriculum change and the College of Medicine, University of Ibadan, Ibadan Nigeria. Afr J Med Med Sci. 2006; 35(3):395-405.

22. Olapade-Olaopa EO; TWG members of the Project, editors. Nigeria Undergraduate Medical and Dental Curriculum Template. Health Systems 20/20 Project. Bethesda, MD: Abt Associates Inc.; 2012.

23. Albanese MA, Mejicano G, Mullan P, Kokotailo P, Gruppen L. Defining characteristics of educational competencies. Med Educ. 2008;42(3):248-255.

24. Drake RL. Anatomy education in a changing medical curriculum. Kaibogaku Zasshi. 1999;74(4):487-490.

25. Muller S. Physicians for the twenty-first century: report of the Project Panel on the general professional education of the physician and college preparation for medicine. J Med Educ. 1984;59:1-28.

26. Harris P, Snell L, Talbot M, Harden RM. Competency-based medical education: implications for undergraduate programs. Med Teach. 2010;32(8):646-650.

27. Ali SK, Baig LA. Problems and issues in implementing innovative curriculum in the developing countries: the Pakistani experience. $B M C$ Med Educ. 2012;12:31.

28. Harden RM. The integration ladder: a tool for curriculum planning and evaluation. Med Educ. 2000;34(7):551-557.

29. McKeown PP, Heylings DJ, Stevenson M, McKelvey KJ, Nixon JR, McCluskey DR. The impact of curricular change on medical students' knowledge of anatomy. Med Educ. 2003;37(11):954-961.

30. Gupta S, Gupta AK, Verma M, Kaur H, Kaur A, Singh K. The attitudes and perceptions of medical students towards basic science subjects during their clinical years: a cross-sectional survey. Int J Appl Basic Med Res. 2014;4(1):16-19.

31. Fitzgerald JE, White MJ, Tang SW, Maxwell-Armstrong CA, James DK. Are we teaching sufficient anatomy at medical school? The opinions of newly qualified doctors. Clin Anat. 2008;21(7):718-724.
Advances in Medical Education and Practice

\section{Publish your work in this journal}

Advances in Medical Education and Practice is an international, peerreviewed, open access journal that aims to present and publish research on Medical Education covering medical, dental, nursing and allied health care professional education. The journal covers undergraduate education, postgraduate training and continuing medical education

\section{Dovepress}

including emerging trends and innovative models linking education, research, and health care services. The manuscript management system is completely online and includes a very quick and fair peer-review system. Visit http://www.dovepress.com/testimonials.php to read real quotes from published authors. 